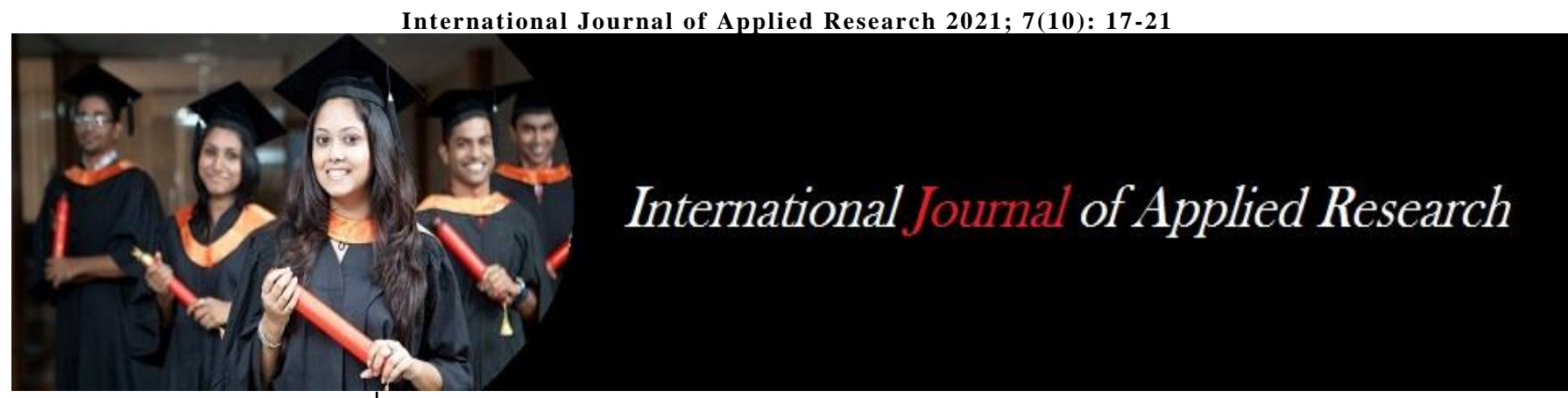

ISSN Print: $2394-7500$ ISSN Online: 2394-5869 Impact Factor: 8.4 IJAR 2021; 7(10): 17-21 www.allresearchjournal.com

Received: 13-08-2021 Accepted: 15-09-2021

Dr. Priyanka Ganjoo Lecturer, Govt. Degree College Akhnoor, Jammu, Jammu and Kashmir, India

\section{Gender socialization: A study among women in Jammu city}

\section{Dr. Priyanka Ganjoo}

DOI: https://doi.org/10.22271/allresearch.2021.v7.i10a.8999

\section{Abstract}

Gender socialization refers to the process of children learning about the social expectations, attitudes, and behaviours that are typically associated with boys and girls. The 'Gender' refers to the socio cultural definition of man and woman, the way societies distinguish men and women and assign them social roles. Each society slowly transforms a male or female into a man or a woman, into masculine and feminine, with different qualities, behaviour patterns and, roles, responsibilities and, rights and expectations. Unlike sex, which is biological, the gender identities of women and men are psychologically and socially- which means historically and culturally determined. Socialization is the process through which individual learns to perform social role. Thus, through gender role socialization girls and boys learn the roles and responsibilities in the society. The present paper has attempted to understand the concept of gender role socialization in the family. The paper has examined the socialization process and the factors that influence gender development in child caring and household activities.

Keywords: gender, socialization, care- giving, house hold, women, men, division of labour

\section{Introduction}

The society has given different set of qualities and characteristics to men and women. Men should have the qualities like strength, bravery, fearlessness, dominance, competiveness and women should have the qualities like caring, nurturing, love, timidity, and obedience. Thus because of these qualities men are considered to be the heads of households, bread winners, owners and managers of property and active in politics. Women on the other hand are expected and trained to bear and look after children, to nurse the infirm and old, do all the household work and so on. These different set of qualities are acquired by the men and women through socialization. The socialization of children plays a very important role in the society. Through socialization, children acquire language, absorb the accumulated knowledge, attitude, beliefs and values of their culture, and learn the social and interpersonal skills they need if they are to function effectively in society. We are socialized through roles, the obligations and expectations attached to a particular status or position in society. The socialization of members and especially girls leads to women themselves accepting their secondary role in family. Dube (2001) says, gender roles are conceived, enacted and learnt within the complex of relationships.

The family is one of the important institutions wherein the socialization of the children takes place. Our society has patriarchal control thus family as a part of society is also controlled by the patriarchy. Millet (1970) claims that the family is the main institution of patriarchy. Within the family it is need for the children to be legitimate, to have a socially recognized father that gives men a particularly dominant position. Mothers and children come to rely for their social status on the position of husbands and fathers in society. The family therefore plays an important part in maintaining patriarchy across generations, socializing children into having different temperaments and leading them to expect and accept roles in later life. This patriarchy system somewhere leads to the gendered division of labour in the society.

Gender division of labour or sexual division of labour refers to the allocation of different roles, responsibilities and tasks to women and men based on societal ideas of what men and women should do and are capable of doing. Men are assigned with the productive work
Corresponding Author:
Dr. Priyanka Ganjoo Lecturer, Govt. Degree College Akhnoor, Jammu, Jammu and Kashmir, India

$$
\sim 17 \sim
$$


whereas women are confined to the reproduction. Reproduction is of two types- biological and social. Biological reproduction refers to giving birth to new human beings, an activity which only women can perform. Social reproduction refers to all the caring and nurturing activities necessary to ensure human survival and maintenance. Reproductive activities, thus, are those activities which reproduce human labour. Caring of children, cooking, feeding, washing, cleaning, nursing and other household activities fall in this category. Although they are necessary for human survival they are neither considered work, nor as an economic activity and hence are invisible, unrecognized and unpaid. Reproductive work is carried out mainly by women and girls across the world.

The division of labour is one of the most fundamental ways that sex distinctions are expressed in the social institutions. The first hunting and gathering societies emerged thousands of years ago. Yet, even at the beginning of the twenty-first century, women and men continue to do different kinds of work. Within families, the gendered division of labour is reflected and most directly in women's and men's differential responsibilities for child-rearing. Women (not men) give birth - a biological fact - but women in most societies have primary responsibility for children's care and rearing. Gender differences in the responsibility for children are an important component of family as a gendered institution, and shape many aspects of women's and men's work and family lives.

Engels argues that the source of the oppression of women came from the exclusion of women from social production and the conversion of household tasks into a private service. Both of these developments resulted from the replacement of communal ownership of property by private male ownership of the basic means of production. In contemporary India, the foundation for parenthood practice begins with early in life. Children in their early childhood years receive encouragement and appreciation for their activities in their playtime. Role playing as mother/father or caregiver provides children with their first experience in handling infants (toys) in cradle, cuddling, bathing, feeding, soothing the crying baby and putting it to sleep. These behaviours are strengthened when children are given the opportunity and responsibilities of being caregivers to younger siblings (or cousins in joint families).

Thus, the different social roles that men and women play are based on a sexual division of labour and according to social role theory, these role differences lead to differences in the behaviours of males and females. Differences in position and power lead to differences in gender roles which include both beliefs and expectations about what men and women do. Women usually hold a position in society that is highly connected with their post as mothers and positions that can be easily combined with childcare. This formula had been done since early history of humans, when women stayed at home or near home for child and husband's need and men specialized in hunting and dangerous activities.

\section{Methodology}

The present paper has attempted to analyze the gender role socialization in family. In order to analyze the same, 60 women respondents were selected purposively from Jammu city which comes under Jammu Municipal Corporation. Thus the whole of the city has been taken into consideration. For data collection both primary and secondary sources has been used. Thus the present study is based on both primary and secondary sources. Primary sources included the first hand information collected from the selected respondents during the fieldwork. For primary data field work was conducted in the area of study using interview method.

Secondary data was collected through using books, journals, articles, internet sources etc. For the analysis of data simple percentage method has been used.

\section{Child-care and household activity}

The natural association of women with housework is rooted in the concept of motherhood. In addition to relying on the family group to reproduce new members, society relies on the family to take care of the young until they are able to survive independently. Gendered patterns of parenting are central to the everyday tasks we call 'child care' as well as to the more highly regarded long-term job of guiding the young to be emotionally and physically healthy as well as conforming members of society.

Childcare and care giving are important activities performed by women. A helpless new-born child requires the care and support of its parents for its physical survival and security, but from both of the parents the sole responsibility regarding child care is done by only mother. Macdonald (1998) [10] describes mother-work activities as "feeding, diapering, bathing, disciplining, putting children to bed, and playing with them...soothing, stimulating, and connecting". She also points out that other important aspects of mothering are conceiving, gestating, and bearing children. She distinguishes these activities as, "separate from motherhood as a social role or identity, mother-work represents a large component of what it means to be a mother, to experience mothering".

Care work is at the core of domestic activities and is the area where gender divides seem hard to change. Caring is both the set of pragmatic tasks of providing physical care and the critical role of ongoing emotional support, where it is difficult to separate out the emotional bond from domestic duties. Housework, child rearing, volunteering and care for the elderly and infirm, whether paid or not, are crucial to human well-being and to the economy. The unwritten assumption is that mothers, grandmothers, aunts, sisters and wives do not expect to be paid because the care work they do is an expression of love. In short they care about their families. Women and men tend to resolve time pressures and conflicts between paid employment and care giving by emphasizing different priorities. Mothers are more likely than fathers to limit their labour force participation, and fathers are more likely than mothers to reduce their care giving responsibilities. That is because women are more likely than men to think about caring for children in the practical sense of taking care of them by watching over them and responding to their immediate needs. Men's sense of caring is more likely to be a good economic provider (Fisher and Tronto, 1990) ${ }^{[13]}$.

In traditional Indian families the roles of wife and mother are clearly defined and separated from that of the father. The domestic roles of men and women do not overlap and are not interchangeable. Men have always attended to the tasks outside the household. The women have a complex constellation of roles: manager of the household; caretaker of the children; and distributor of love and affection. Even in the new familial reality, based on affection among its members, in the greater intimacy between husband and wife 
and between parents and children, still the family became centered in the wife-mother figure. Women as mothers came to be mainly responsible for the well-being of the children and the husband, and became an important intermediary between the fathers, ever more absent due to work outside the home, and the children. The society believes that the maternal skills are natural because it is automatically come to the women after the birth of the child. Because the maternal skills are considered as natural, women take all the responsibilities of taking care of children in the family.

The myth of femininity encapsulated by the notion of the 'maternal instinct' is the one through which women's psychology and social role are determined scientifically (Apter, 1993) ${ }^{[15]}$. The myth may be summarised thus; all women have asexual drive towards conceiving and bearing children. This is a precursor to the drive to nurture those children. The skills/capacities required to care for infants/children emerge or evolve immediately after the birth without the need for training. The logical consequence of this 'instinct' would be the knowledge that all women want to (and thus should be enabled to) have children, and are capable of looking after them without training. The 'maternal instinct' cuts across ideas that women are socialized into wanting children - it is a biological imperative (Buss, 1994) ${ }^{[16]}$.

Chodorow (1978) ${ }^{[17]}$ has suggested that this 'reproduction' of mothering within the context of patriarchy, although not a biological imperative is in one sense both 'natural' and 'inevitable' for women, given the dominant social structures. Women's mothering is not only a product of biology, but also causally related to historical conditions and the way that child-care and the division of labour have evolved. She argues that girls/women and boys/men develop in a context which encourages the psychological capacities and commitments to participate in the existing social relations and structures. The dominant structures, whereby women mother and men work outside the home, are accompanied by appropriate psychological capacities which underlie these tasks, and these are reproduced at both conscious and unconscious levels: Women as mothers, produce daughters with mothering capacities and the desire to mother. These capacities and needs are built into and grow out of the mother-daughter relationship itself.

From time immemorial, childrearing responsibilities have been borne by the mother. The mother is supposed to have a maternal instinct that is aroused automatically as soon as she conceives and becomes aware of it. The infant spends most of his/her initial time with the mother following birth and thus becomes highly attached to the mother and other caregivers. Mothers typically fulfil the role of caregiver and thus meet the child's needs for basic security.

Table 1: Maternal Skills

\begin{tabular}{|c|c|c|}
\hline Response & Number of Respondents & Percentage \\
\hline Natural & 10 & 16.7 \\
\hline Learnt & 34 & 56.7 \\
\hline Both & 16 & 26.6 \\
\hline Total & 60 & 100 \\
\hline
\end{tabular}

When the respondents were asked about the maternal skills being natural or learnt, the response was given as 16.7 per cent (10 out of 60) said that maternal skills are natural, 56.7 per cent (34 out of 60) said that maternal skills are learnt and 26.6 per cent (16 out of 60) said that maternal skills are both natural as well as learnt. Whatever a woman do as a mother is learnt or she is socialized in such a way that a woman considered maternal skill as natural and sometimes place the category of maternal skills as both natural and learnt. Douglas and Michaels (2004) ${ }^{[18]}$ have established that the Maternal Instinct is not natural among women; mothering does not come automatically to women and the perception of motherhood changes according to time, social and economic circumstances. It is believed that whenever a woman becomes mother she is expected to take care of the child for that she needs no advice and assistance because it is believed that the care comes naturally to the women.

Table 2: Women's duty to take care of their children

\begin{tabular}{|c|c|c|}
\hline Response & Number of Respondents & Percentage \\
\hline Yes & 18 & 30 \\
\hline No & 42 & 70 \\
\hline Total & 60 & 100 \\
\hline
\end{tabular}

The table shows that 30 per cent (18 out of 60 ) of the respondents who responded positively on the question whether it is women's duty to perform childcare and 70 per cent (42 out of 60) believed that it is not just their duty but of other family members as well to take care of the children. From the fieldwork it was observed that women are still taking care of their children within the family. The mother plays a pivotal role in the life of a child, especially in India where the child rearing responsibilities are essentially assigned to her. It can also be said that in the society there is the gendered division of labour because of which fathers and mothers have different involvements in activities that facilitate children's growth, fathers are less inclined to see sharing in child-rearing decisions and activities, possessing knowledge of children and child rearing techniques.

The society has given women the responsibilities of keeping the family together and help family to run smoothly. Women are expected to perform the household chores which include washing clothes and utensils, cooking food and teaching children at home. The tasks done by the women are not according to some schedule but have to do all the tasks for the whole day with no holidays that is they have to work for 24 hours in a week. Women as mothers perform various tasks in the family and some of the roles that they perform include the following: mothers have an important role in teaching children. Their goal is to raise their kids so they can become pioneers of the society. Whether it's breakfast, lunch, dinner all are prepared by the mother for her children as well for the family. The washing of the clothes, the ironing of the clothes, cleaning of the rooms, management of the house that is all done by the mothers. As the child is small, the training of the child is important like how to eat, how to sit, how to behave, how to talk, toilet training etc. all this work is done by the mothers.

Other works done by the mothers include to change the nappies of the children, to play with them, put them to sleep at night, attend to children at night, bathing children, taking children to the school and tuitions, get the children back from the school and tuitions, take children for shopping, do knitting and sewing clothes for them and so on. These all works take lot of patience and time. In the family, women take most of the responsibility of the childcare and domestic chores, and men take very less responsibility of childcare and domestic chores. 
Table 3: Men performs following tasks for children

\begin{tabular}{|c|c|c|c|c|}
\hline S. No. & Tasks & Yes & No & Total \\
\hline 1 & Give meals to them & 9 & 51 & 60 \\
\hline 2 & Bathe them & 10 & 50 & 60 \\
\hline 3 & Change their nappies & 8 & 52 & 60 \\
\hline 4 & Play with them & 24 & 36 & 60 \\
\hline 5 & Get them to sleep & 5 & 55 & 60 \\
\hline 6 & Attend to them in night & 8 & 52 & 60 \\
\hline 7 & Take them out without you & 15 & 45 & 60 \\
\hline
\end{tabular}

The table no. 3 shows that 9 out of 60 respondents said that their husbands give meals to children, 10 out of 60 respondents said their husbands bathe their children, 8 out of 60 respondents said that their husband change nappies of their children, 24 out of 60 respondents said that their husband play with children, 5 out of 60 respondents said that husband get the children sleep at night, 8 out of 60 respondents said that their husband attend children in night and 15 out of 60 respondents said that their husband take children outside without them. Thus on the basis of the following response given by the respondents it can be said that there is very less involvement of the men in the avenue of the child care. Most of the works regarding the child care are done by the female only. The society considers that the child care require the presence of mother more than the presence of father. The primary responsibility of childcare lies with women because of the biological fact of childbearing and lactation. When a man does housework, it is often seen as helping his wife. Housework is not just hard work but is invisible also because it is considered economically unproductive.

Boulton (1983) ${ }^{[22]}$ argues that women exaggerate the extent of men's involvement in childcare. Boulton claims that, although men might help with particular tasks, it is their wives who retain primary responsibility for children. It is their wives who relegate non-domestic aspects of their lives to a low priority. Some empirical support for Boulton is provided by a study conducted by Ferri and Smith (1996) ${ }^{[23]}$. They have produced data based upon the National Child Development Survey. The survey found that it was still very rare for fathers to take primary responsibility for childcare. In both the sample of mothers and the sample of fathers it was very rare in dual-earner families, no earner families or families where only the mother worked, for the man to be normally responsible for the children or to look after them when they are ill. Even when the women had paid employment outside the home and the man did not, it was still more common for the woman than the man to take main responsibility for routine childcare in the event of illness. Within the family, women have been responsible for domestic and emotional labour and for childcare and have thus been prevented from playing a full part in public life.

Today, women have a well theorized attachment to the workplace and both women and mothers participate as economically productive citizens. However, child care and domestic duties still overwhelmingly appear to remain the responsibility of the mother, placing a significant 'double burden' on mothers (Eveline, 2001; Thurer, 1994) ${ }^{[24,25] .}$ When women are doing job outside the home they have to perform all the tasks equally and perfectly whether the task is regarding the childcare or the household chores. Mothers whether they are stay at home mothers or working mothers, both perform dual responsibility.
Table 4: Occupational status

\begin{tabular}{|c|c|c|}
\hline Occupation & Number of Respondents & Percentage \\
\hline Working & 23 & 38.3 \\
\hline Non-working & 37 & 61.7 \\
\hline Total & 60 & 100 \\
\hline
\end{tabular}

As regards the occupational status of the respondents 38.3 per cent (23 out of 60) are paid workers, doing different kinds of occupation. 61.7 per cent (37 out of 60) are nonpaid workers.

Table 5: Occupational status of working respondents

\begin{tabular}{|c|c|c|}
\hline Occupation & $\begin{array}{c}\text { Number of } \\
\text { respondents }\end{array}$ & Percentage \\
\hline Government employee & 4 & 17.5 \\
\hline Business & 2 & 8.7 \\
\hline Teacher & 9 & 39.1 \\
\hline Bank employee & 5 & 21.7 \\
\hline Other & 3 & 13.0 \\
\hline Total & $23^{*}$ & 100 \\
\hline
\end{tabular}

*Only working respondents are taken in the table

Table shows 17.5 per cent (4 out of 23) are working as Government employee, 8.7 per cent ( 2 out of 23) are doing business, 39.1 per cent ( 9 out of 23) are doing job as a teacher, 21.7 per cent ( 5 out of 23 ) are bank employee and 13.0 per cent ( 3 out of 23 ) doing other jobs. It can be seen that respondents from various occupations have been taken for the study. No doubt, women who are the home makers have the responsibility of taking care of the children but the women who are doing job outside the home also have the responsibility of taking care of children. Thus it is clear that whether the woman is home maker or doing job outside the home, both are considered as responsible for taking care of children.

It is clear from the above discussion that men are performing lesser childcare and ultimately the care of the children is limited to the women because of which they do not even get time for themselves. The capability of bearing a child makes women to confine her to the childcare which becomes the reason that women do not get time for themselves.

Purdy (1997) ${ }^{[26]}$ argues that women are disadvantaged and exploited in family relationships. She believes that these disadvantages largely result from childcare responsibilities rather from material inequalities. According to Purdy, there are number of disadvantages for women in having children. Having children is extremely expensive and can increase the burden of poverty on women who are already poor. Having children represents a commitment for women for the rest of their lives, and a particularly onerous commitment during the first 18 years. Purdy believes that society in general takes it for granted that women will have children and therefore perform the vital function of reproducing the species. The only way to bring home to men the sacrifices of child-rearing is for women to stop having children. In other words, Purdy advocates a baby tike, only then would men take women's demands for equality within families seriously. Only then would social arrangements change so that women were able to combine having children with successful careers.

\section{Conclusion}

Thus it can be concluded as from the birth, male and female infants are treated differently by their parents, as parents are 
the child's first and the most influential socializing agent has a great impact on the bringing up of the children. In the family, both male and female child are treated differently. The house hold tasks that are divided between the parents and their children are also gender specific. Childcare and cleaning are typically assigned to daughters and home maintenance work to sons. The girls are also invariably entrusted with the duty of looking after the younger siblings, a task not allotted to boys. Thus, from the childhood girls are socialized regarding the care of the children and the household activities.

\section{References}

1. Bhasin Kamla. Understanding Gender. New Delhi, Kali for Women, 2000.

2. Coltrane Scott. Household Labor and the Routine Production of Gender, Social Problems. 1989;36(5):473-490.

3. Dube Leela. Anthropological Explorations in Gender: Intersecting Fields Sage Publications, New Delhi, 2001.

4. Millet K. Sexual Politics. Doubleday, New York, 1970.

5. Haralambos Michael and Holbron Martin. Sociology: Themes and Perspectives, Collins, London, 2000.

6. Chowdhury Aparajita; Carson K. David and Carson K. Cecyle. (ed.) Family Life Education in India: Perspectives, Challenges and Applications. Rawat Publications, Jaipur, 2006.

7. Wharton A.S. The Sociology of Gender: An Introduction to Theory and Research. UK, Wiley Blackwell, 2012.

8. Kramer Laura. The Sociology of Gender: A Brief Introduction. Rawat Publications, Jaipur, 2004.

9. Tapan Neeta. Need For Women Empowerment. Rawat Publication, Jaipur, 2000.

10. Macdonald CL. Manufacturing Motherhood: The Shadow Work of Nannies and Au Pairs, Qualitative Sociology. 1998;21(1):25-53.

11. Cheal David. Sociology of Family Life. Palgrave, New York, 2002.

12. Harcourt Wendy. Body Politics in Development: Critical Debate in Gender and Development. Zedd Books, London, 2009.

13. Fisher B and Tronto J. "Toward a Feminist Theory of Caring", in F. Abel \& M. Nelson (eds.): Circles of Care State University of New York, Albany, 1990.

14. Ghadially R (Ed.). Women in Indian Society: A Reader. Sage Publications, New Delhi, 1988.

15. Apter T. Professional Progress: Why Women still Don't Have Wives. Macmillan, London, 1993.

16. Buss DM. 'The Strategies of Human Mating', American Scientists, 1994;82:238-249.

17. Chodorow Nancy. The Reproduction of Mothering: Psychoanalysis and the Sociology of Gender. University of California Press, Berkeley, 1978.

18. Douglas Susan J. and Meredith Micheals W. The Mommy Myth: The Idealization of motherhood and how it has undermined women free press, New York, 2004.

19. P Abbott $\mathrm{C}$ Wallace and $\mathrm{T}$ Melissa. An Introduction to Sociology; Feminist Perspectives New York; Routledge, 2005.

20. Bhattacharya Rinki (Ed.) Janani: Mothers, Daughters, Motherhood. Sage Publications, New Delhi, 2006.
21. Reskin FB and Peavic I. Women and men at work Thousand Oaks, Pine Forge Press, London, 1994.

22. Boulton MG. On Being a Mother Tavistock, London, 1983.

23. Ferri Elisa and Smith Kate. Parenting in the 1990s. Family Policy studies Centre, London, 1996.

24. Joan Eveline 'Whither the "New Father"? Male Managers and Early Childcare in Australia and Sweden', Journal of Interdisciplinary Gender Studies, 2001;6 (1):3-20.

25. Thurer S. The Myths of Motherhood: How Cultures Reinvent the Good Mother Penguin Books, New York, 1994.

26. Purdy LM. 1997. 'Baby Strike' in Michael Haralambos and Martin Holbron. Sociology: Themes and Perspectives Collins, London, 2000. 